\title{
Feeding of bakery by-products in the replacement of grains enhanced milk performance, modulated blood metabolic profile, and lowered the risk of rumen acidosis in dairy cows
}

A. Kaltenegger, (1) E. Humer, $\odot$ A. Stauder, $\odot$ and Q. Zebeli* $\odot$

Institute of Animal Nutrition and Functional Plant Compounds, Department for Farm Animals and Veterinary Public Health, University of Veterinary Medicine, Veterinärplatz 1, 1210 Vienna, Austria

\begin{abstract}
Leftover bakery by-products (BP) from bakeries and supermarkets may serve as energy-rich ingredient in ruminant diets. The aim of the present study was to evaluate the effect of the successive substitution of cereal grains by BP on dry matter (DM) intake, milk production, and metabolic health as well as ruminal $\mathrm{pH}$ and eating and chewing behavior of dairy cows. Twenty-four lactating Simmental cows (149 \pm 22.3 $\mathrm{d}$ in milk, lactation number $2.63 \pm 1.38,756 \pm 89.6$ $\mathrm{kg}$ of initial body weight) were fed a total mixed ration containing a 50:50 ratio of forage to concentrate throughout the experiment $(35 \mathrm{~d})$. During the first week, all cows received a control diet (without BP) as a baseline ( $\mathrm{d}-7$ to 0 ). In the next 4 wk (d 1 to 28 ), cows were allocated to 3 groups differing in the $\mathrm{BP}$ concentrations of diets $[0 \% \mathrm{BP}(\mathrm{CON}), 15 \% \mathrm{BP}$, and $30 \% \mathrm{BP}$ on a DM basis]. The DM intake and reticuloruminal $\mathrm{pH}$ were continuously measured. Blood and milk samples were taken every week, but only results from the experimental period (d 21 and 28) were used for statistical analyses, whereas results from the baseline were considered covariates. Diet analyses showed that BP inclusion increased the ether extract and sugar contents, whereby starch and neutral detergent fiber decreased. Experimental data showed that feeding BP in the diet increased DM intake. Furthermore, the cows fed $30 \% \mathrm{BP}$ produced roughly $4 \mathrm{~kg} / \mathrm{d}$ more milk and energy-corrected milk than the CON cows. The milk urea nitrogen was lower in cows fed the BP. Feeding BP reduced the blood glucose and insulin concentrations, whereas nonesterified fatty acids, $\beta$-hydroxybutyrate, and cholesterol increased linearly. Cows fed $15 \%$ BP had the shortest period of time in which ruminal $\mathrm{pH}$ was below 5.8 , in contrast to CON cows $(+188 \mathrm{~min} / \mathrm{d})$. Taken together, the results suggest that the inclusion
\end{abstract}

Received February 25, 2020.

Accepted June 22, 2020.

*Corresponding author: qendrim.zebeli@vetmeduni.ac.at of up to $30 \% \mathrm{BP}$ in the diets of mid-lactation dairy cows shifted the nutrient profile from a glucogenic diet to a lipogenic diet, holding the potential to enhance performance and lower the risk of subacute ruminal acidosis in dairy cows.

Key words: bakery by-product, dairy cow, performance, metabolic health, ruminal $\mathrm{pH}$

\section{INTRODUCTION}

Starchy grains have become an important part of the dairy cow diet. Grains are highly palatable, less bulky, and rich in minerals, and they are a relatively cheap and safe source of metabolizable energy in the diet of high-producing dairy cows (Humer and Zebeli, 2017). However, cereal grains are human-edible ingredients, and their reduction in ruminant feeding has recently become more important to increase net food production, which is defined as human-edible livestock products (output) minus human-edible feeds (input); this might improve sustainability in livestock production (Ertl et al., 2016). Another critical aspect of using grains in cattle feeding is that starchy grains are associated with several health risks, especially rumen fermentation disorders such as SARA. Cows that have SARA have impaired digestion and higher odds of developing other diseases, thus compromising the health and welfare of the animals and being a concern for the dairy industry (Plaizier et al., 2008).

The increasing availability of by-products from various food industries has long raised interest in animal nutrition (Bradford, 1999; Eastridge, 2006). Besides common by-products, bakeries and supermarkets also generate large amounts of wasted bakery products (BP), consisting mainly of unsold products (i.e., unsold sliced bread, croissants, biscuits, cakes, dough), which are not consumed largely due to consumer preferences for fresh products (Hetherington and Krebs, 2002; Eastridge, 2006; França et al., 2012). From a regulatory point of view they are considered feed ingredients, and their use in animal nutrition would help recycling and valorizing 
the wasted food. Nutritionally, the BP supply slightly higher energy content, and the profile of energy precursors is different from starchy grains. For example, although the BP contain less starch, they contain more fat and sugars and less fiber than the native cereal grains (Humer et al., 2018a). An additional aspect that needs to be taken into consideration when feeding BP in cattle relates to chemical changes that occur during baking. Indeed, the extent of processing during baking might be a concern from a ruminant nutrition perspective because extensive treatments (i.e., grinding, heating) might increase ruminal starch degradation in a way that could affect feed intake as well as rumen and metabolic health (Offner et al., 2003; Drouillard, 2016). Most important, a possible increase in starch digestibility by baking might cause a rapid accumulation of short-chain fatty acids (SCFA) and a rapid decrease in ruminal $\mathrm{pH}$ and hence SARA conditions (Plaizier et al., 2008). Also, both the altered chemical composition of nutrients and a shift in the SCFA profile in the rumen might modulate rumen-derived metabolic precursors (mainly acetate, propionate, and butyrate), resulting in a modification of milk composition and metabolic patterns of cows (Bernard et al., 2009; Oba et al., 2015; Razzaghi et al., 2016).

Recently, we conducted an in vitro trial aiming to replace common cereal grains with a mixture of BP. In this research we found that up to $30 \%$ BP in the substrate did not adversely affect the $\mathrm{pH}$ and microbial diversity in the rumen but did increase the proportion of propionate, suggesting a potential for a higher glucose supply in cattle (Humer et al., 2018a). However, the effects of replacing grains with $\mathrm{BP}$ on feed intake, ruminal fermentation patterns, chewing activity, production performance, and metabolic profile of dairy cows have not yet been investigated. Therefore, the main aim of this study was to evaluate the effects of the graded substitution of cereal grains by BP on DMI, milk production, and ruminal $\mathrm{pH}$ combined with monitoring the eating, ruminating, and feed-sorting behavior of the cows. Our hypothesis was that feeding up to $30 \%$ $\mathrm{BP}$ in the diet would be well tolerated by cows without shortcomings in DMI, milk performance, and metabolic profile. Another aim of the research was to evaluate the influence of BP feeding on rumen health. Because of nutrient profile shifts, especially decreased fiber and a potential increase of starch digestibility during the baking process, we hypothesized that feeding 30\% BP in the diet might increase the risk of SARA in cows.

\section{MATERIALS AND METHODS}

All procedures involving animal handling and treatment were approved by the institutional ethics commit- tee of the University of Veterinary Medicine (Vetmeduni) Vienna and the national authority according to $\S 26$ of the Law for Animal Experiments, Tierversuchsgesetz 2012- TVG (GZ: 68.205/80-V/3b/2018).

\section{Animals, Housing, and Experimental Design}

The experiment was conducted from September 2018 to February 2019 at the dairy research farm of Vetmeduni Vienna (Pottenstein, Austria). A total of 24 lactating Simmental cows averaging $149 \pm 22.3$ DIM, with mean lactation number of $2.63 \pm 1.38$, an initial BW of $756 \pm 89.6 \mathrm{~kg}$, and producing $29.6 \pm 0.32 \mathrm{~kg}$ of ECM at the start of the trial, were used in this research. Cows were housed in a freestall with 16 deep litter cubicles and a deep bedded pack area $(10 \times 8 \mathrm{~m})$. The trial was arranged in 3 subsequent longitudinal runs, each lasting for $35 \mathrm{~d}$ : $7 \mathrm{~d}$ for baseline measurements ( $d-7$ to 0 ), $14 \mathrm{~d}$ for adaptation (d 1 to 14 ), and $14 \mathrm{~d}$ for sampling (d 15 to 28) and data recording. During the 7-d baseline period, cows received the same diet (without BP), and measurements taken from each cow during baseline ( $\mathrm{d}-5$ to 0 ) were used as covariate in the statistical analyses. After this covariate period, cows were randomly allocated to 3 experimental groups $(\mathrm{n}=8)$, blocking them by DIM, milk yield, feed intake, and parity. The experimental groups differed in the $\mathrm{BP}$ concentrations of their diets. On a DM basis, the control (CON) group was fed $0 \%$ BP but $30 \%$ grains in the concentrate, whereas the other 2 experimental groups were fed either $15 \%$ BP plus $15 \%$ grains (15\% $\mathrm{BP}$ group) or $30 \% \mathrm{BP}$ without grains (30\% BP group) in their concentrates. Diets were fed as TMR containing $50 \%$ concentrates, $25 \%$ corn silage, and $25 \%$ grass silage (on a DM basis) throughout the experiment. A detailed list of ingredients and the analyzed chemical composition of the diets is shown in Table 1. The BP used in this experiment was supplied as a single batch from a local feed company (Königshofer GmbH, Ebergassing, Austria), which collected BP from Viennese bakeries and supermarkets after undergoing common quality control. The analyzed chemical composition of the BP used in this experiment as well as that as of grains used to substitute them are shown in Table 2. The BP was dried, milled, mixed, and pelleted together with the other ingredients of the concentrate. The TMR was prepared by an automatic feeding system (Trioliet Triomatic T15, Oldenzaal, the Netherlands) between 1400 and $1500 \mathrm{~h}$. One half of the fresh feed was offered at about $1500 \mathrm{~h}$, and the other half was offered the next day after morning milking $(0730 \mathrm{~h})$. Cows were fed individually ad libitum to allow between 5 and $10 \%$ orts daily, which were removed every day before preparing the fresh TMR. Furthermore, cows had continuous free 
Table 1. Ingredients and chemical composition (\% of DM unless stated) of experimental diets not containing (CON) or containing 15 and $30 \%$ bakery by-products (BP)

\begin{tabular}{|c|c|c|c|}
\hline \multirow[b]{2}{*}{ Item } & \multicolumn{3}{|c|}{ Experimental diet } \\
\hline & $\mathrm{CON}$ & $15 \% \mathrm{BP}$ & $30 \% \mathrm{BP}$ \\
\hline \multicolumn{4}{|l|}{ Ingredient } \\
\hline Grass silage & 25.0 & 25.0 & 25.0 \\
\hline Corn silage & 25.0 & 25.0 & 25.0 \\
\hline Wheat & 22.5 & 11.3 & - \\
\hline Triticale & 7.5 & 3.8 & - \\
\hline Rapeseed meal & 17.0 & 17.0 & 17.0 \\
\hline Bakery by-products & - & 15.0 & 30.0 \\
\hline Mineral-vitamin premix ${ }^{1}$ & 1.0 & 1.0 & 1.0 \\
\hline Molasses & 1.5 & 1.5 & 1.5 \\
\hline Limestone & 0.5 & 0.5 & 0.5 \\
\hline \multicolumn{4}{|l|}{ Chemical composition } \\
\hline DM (\% of fresh matter) & 46.1 & 46.2 & 47.4 \\
\hline Ash & 7.50 & 7.27 & 7.47 \\
\hline $\mathrm{CP}$ & 15.9 & 16.5 & 16.7 \\
\hline $\mathrm{NDF}$ & 34.5 & 34.6 & 31.0 \\
\hline $\mathrm{ADF}$ & 23.9 & 22.7 & 21.4 \\
\hline Ether extract & 2.40 & 3.10 & 4.00 \\
\hline Starch & 23.6 & 22.3 & 21.4 \\
\hline Sugars & 4.50 & 5.60 & 5.97 \\
\hline $\mathrm{NE}_{\mathrm{L}}(\mathrm{MJ} / \mathrm{kg}$ of $\mathrm{DM})$ & 6.50 & 6.96 & 7.24 \\
\hline Calcium & 0.91 & 0.96 & 0.98 \\
\hline Phosphorus & 0.47 & 0.47 & 0.49 \\
\hline Magnesium & 0.35 & 0.35 & 0.36 \\
\hline Potassium & 1.60 & 1.59 & 1.51 \\
\hline Sodium & 0.08 & 0.14 & 0.22 \\
\hline \multicolumn{4}{|l|}{$\begin{array}{l}\text { Particle size distribution } \\
( \pm \mathrm{SD})\end{array}$} \\
\hline$>19 \mathrm{~mm}$ & $16.7 \pm 6.64$ & $15.6 \pm 5.14$ & $15.1 \pm 5.51$ \\
\hline $8.0-19.0 \mathrm{~mm}$ & $52.0 \pm 5.26$ & $49.3 \pm 3.94$ & $47.0 \pm 6.72$ \\
\hline $1.18-8.0 \mathrm{~mm}$ & $28.8 \pm 4.67$ & $31.8 \pm 3.8$ & $34.1 \pm 4.93$ \\
\hline \multirow{2}{*}{\multicolumn{4}{|c|}{$\operatorname{peNDF}^{2}( \pm \mathrm{SD})$}} \\
\hline & & & \\
\hline$>8 \mathrm{~mm}$ & $24.4 \pm 4.42$ & $23.0 \pm 3.82$ & $20.4 \pm 4.14$ \\
\hline$>1.18 \mathrm{~mm}$ & $34.4 \pm 4.93$ & $34.2 \pm 4.53$ & $31.3 \pm 4.10$ \\
\hline
\end{tabular}

${ }^{1}$ Contained $16.0 \% \mathrm{Ca}, 11.5 \% \mathrm{Mg}, 7.8 \% \mathrm{P}, 2.2 \% \mathrm{Na}, 2,300,000 \mathrm{IU}$ of vitamin $\mathrm{A} / \mathrm{kg}, 240,000 \mathrm{IU}$ of vitamin $\mathrm{D}_{3} / \mathrm{kg}, 5,000 \mathrm{mg}$ of vitamin $\mathrm{E} /$ $\mathrm{kg}, 2,000 \mathrm{mg}$ of vitamin $\mathrm{B}_{1} / \mathrm{kg}, 3,600 \mathrm{mg}$ of copper sulfate $/ \mathrm{kg}, 23,750$ $\mathrm{mg}$ of zinc oxide $/ \mathrm{kg}, 16,200 \mathrm{mg}$ of manganese oxide $/ \mathrm{kg}, 270 \mathrm{mg}$ of cobalt carbonate $/ \mathrm{kg}, 540 \mathrm{mg}$ of iodine (calcium iodine) $/ \mathrm{kg}, 130 \mathrm{mg}$ of selenium (sodium selenite) $/ \mathrm{kg}$.

${ }^{2}$ Physically effective NDF (determined according to Kononoff et al., 2003).

access to water and salt blocks. Each cow was equipped with an ear tag as identification sensor enabling an individual feeder. Hence, feed intake was continuously recorded by electronic weighing scales and computerregulated access gates (Insentec B.V., Marknesse, the Netherlands) throughout the day. Additionally, all cows were weighed at the beginning and at end of the trial.

\section{Milk Sampling}

Cows were milked twice a day at 0700 and $1730 \mathrm{~h}$ in a $4 \times 4$ tandem milking parlor (DeLaval GmbH, Eugendorf, Austria). Daily milk yield was registered by an electronic machine recorder (DeLaval Corp.,
Tumba, Sweden). The ECM $(\mathrm{kg} / \mathrm{d})$ was calculated as follows: $(0.38 \times$ milk fat $\%+0.21 \times$ milk protein $\%$ $+0.95) \times \mathrm{kg}$ of milk/3.2 (GfE, 2001). Milk samples were taken from the morning and afternoon milkings by in-line samplers on the last day of baseline (d 0$)$ and on d 14, 21, and 28 to measure milk composition. A few milliliters of the morning milking samples was provided with a conservation liquid (Eco Bronysolv GK145, ANA.LI.TIK. Austria, Vienna, Austria) and cooled at $4^{\circ} \mathrm{C}$ until afternoon milking. At the end of the day, the samples of the afternoon milking were added in approximately equal amounts to those of the morning milking, shaken by hand, and stored at $4^{\circ} \mathrm{C}$ until analyzed for contents of fat, protein, lactose, MUN, and SCC as well as milk pH using infrared spectrophotometry (CombiFoss TM7, Foss, Hillerød, Denmark).

\section{Blood Sampling and Analyses}

Blood samples were taken at the end of baseline (d 0) and on d 14, 21, and 28 shortly before morning feeding; on d 21 and 28, blood samples were additionally collected 6 and $12 \mathrm{~h}$ after morning feeding. Samples were taken from the jugular vein using 9-mL serum evacuated tubes and 6-mL evacuated tubes containing sodium fluoride-potassium oxalate (Vacuette, Greiner Bio One International $\mathrm{GmbH}$, Kremsmünster, Austria). Serum tubes were allowed to clot for $2 \mathrm{~h}$ at room temperature, whereas plasma tubes were immediately stored at $4^{\circ} \mathrm{C}$ for $2 \mathrm{~h}$. Samples were centrifuged at $2,000 \times g$ at $4^{\circ} \mathrm{C}$ for $15 \mathrm{~min}$, and serum or plasma were stored in 2-mL tubes (Sarstedt, AG, Wiener Neudorf, Austria) at $-20^{\circ} \mathrm{C}$ until analysis. Concentrations of glucose in plasma and nonesterified fatty acids (NEFA), BHB, cholesterol, and liver enzymes such as aspartate aminotransferase, glutamate dehydrogenase, and $\gamma$-glutamyltransferase as well as calcium and phosphorous in serum were

Table 2. Analyzed chemical composition (\% of DM unless stated) of bakery by-product (BP) and cereal grains

\begin{tabular}{lrrr}
\hline Item & BP & Wheat & Triticale \\
\hline DM (\% of fresh matter) & 90.8 & 88.4 & 88.4 \\
Ash & 3.4 & 1.7 & 2.5 \\
CP & 13.9 & 16.0 & 17.4 \\
NDF & 7.1 & 11.4 & 15.3 \\
ADF & 2.3 & 3.7 & 6.6 \\
Ether extract & 10.9 & 1.9 & 5.5 \\
Starch & 50.4 & 66.3 & 52.9 \\
Sugars & 10.6 & 2.8 & 4.9 \\
NE (MJ/kg of DM) & 9.1 & 8.6 & 8.7 \\
Calcium & 0.14 & 0.08 & 0.12 \\
Phosphorus & 0.28 & 0.36 & 0.45 \\
Magnesium & 0.11 & 0.15 & 0.18 \\
Potassium & 0.39 & 0.40 & 0.68 \\
Sodium & 0.64 & 0.01 & 0.02 \\
\hline
\end{tabular}


analyzed using standard enzymatic colorimetric assays with a fully automated analyzer for clinical chemistry (Cobas 6000/c501, Roche Diagnostics GmbH, Vienna, Austria) at the laboratory of the Central Clinical Pathology Unit, University of Veterinary Medicine, Vienna, Austria. Serum concentrations of insulin were measured with an xMarkTM Microplate Absorbance Spectrophotometer (Bio-Rad Laboratories GesmbH, Munich, Germany) using the respective methods and kits (Mercodia Bovine Insulin ELISA, Mercodia AB, Uppsala, Sweden) and haptoglobin $(\mathbf{H p})$ was determined using a commercially available bovine ELISA kit (Genway Biotech Inc., San Diego, CA). All samples of $\mathrm{Hp}$ were diluted 1:50, and only for a small number of samples was a greater dilution necessary (1:100 to 1:750). The intra-assay variation for $\mathrm{Hp}$ and insulin was controlled by a variation coefficient of $\leq 10 \%$.

\section{Feed Sampling and Nutrient Analysis, Particle Size Distribution, and Feed Sorting}

Samples of the fresh TMR and the orts of the following day were taken 4 times $(\mathrm{d}-5,4,17$, and 26) during each experimental run for nutrient analysis and determination of physically effective NDF (peNDF) and feed sorting. Nutrient analyses of feed samples were evaluated in duplicate according to the German Handbook of Agricultural Experimental and Analytical Methods (VDLUFA; Naumann and Bassler, 2012). The DM of the wet feed samples was determined by forced-air drying at $55^{\circ} \mathrm{C}$ for $48 \mathrm{~h}$ and the residual water was subsequently analyzed by oven drying at $105^{\circ} \mathrm{C}$ for $4 \mathrm{~h}$ (method 3.1). The ash content was analyzed by incineration of samples at a temperature of $550^{\circ} \mathrm{C}$ (method 8.1). The Dumas method (method 4.1.2.) was used to analyze the CP content. The ADF content was evaluated using method 6.5.2, whereas the NDF content was pretreated with amylase using method 6.5.1 of VDLUFA (Naumann and Bassler, 2012). The starch content was determined polarimetrically (method 7.2.1). Ether extract (EE) was measured by extraction with petroleum ether (method 5.1.1). The content of $\mathrm{NFC}$ was calculated as $\mathrm{NFC}=\mathrm{DM}-($ ash $+\mathrm{CP}+$ $\mathrm{EE}+\mathrm{NDF}$ ). The Luff-Schoorl method according to method 7.1.1 of VDLUFA was conducted to analyze the sugar concentration (Naumann and Bassler, 2012). The $\mathrm{NE}_{\mathrm{L}}$ content of diets was determined by including nutrients and gas production of the in vitro fermentation of feedstuffs according to GfE (2001). The contents of phosphorus, calcium, magnesium, potassium, and sodium were determined by inductively coupled plasma emission spectroscopy following method 10.8.2 of VDLUFA (Naumann and Bassler, 2012).
To determine sorting behavior and the peNDF content, fresh samples of the TMR were taken on $\mathrm{d}-5,4$, 17, and 26 after preparing the fresh TMR, and refusals were taken on the following day before cleaning the feeding troughs. Samples were sieved after feeding the fresh TMR using the method of Kononoff et al. (2003). The Penn State Particle Separator (model C24682N, Nasco, Fort Atkinson, WI) includes 3 screens and separates the feed samples into 4 fractions based on particle size: long $(>19 \mathrm{~mm})$, medium $(8-19 \mathrm{~mm})$, short $(1.18-8$ $\mathrm{mm})$, and fine $(<1.18 \mathrm{~mm})$. The sorting index was calculated by dividing the actual intake of each fraction by the predicted intake expressed as a percentage. Sorting index values $>100$ indicated that cows sorted in favor of these particles, values $<100$ indicated sorting against particles, and a value of 100 implied no sorting (Leonardi and Armentano, 2003). The NDF content was multiplied by the sum of the retained long and medium particles to calculate the peNDF of 2 sieves ( $\left.\mathbf{p e N D F} \mathbf{F}_{>\mathrm{mm}}\right)$ and was multiplied by the sum of long, medium, and short particles to calculate the peNDF of 3 sieves $(\mathbf{p e N D F}>1.18 \mathrm{~mm})$.

\section{Reticuloruminal $\mathrm{pH}$}

A total of 20 cows received indwelling wireless ruminal pH sensors (smaXtec Animal Care GmbH, Graz, Austria) that allowed continuous monitoring of reticuloruminal $\mathrm{pH}$ and temperature. The same type of sensors was validated by Klevenhusen et al. (2014). After calibration with a buffer of $\mathrm{pH} 7.0$, sensors were manually inserted into the reticulorumen through the esophagus. The units $(3.5 \mathrm{~cm}$ i.d., $12 \mathrm{~cm}$ long, and weighing 210 g) measured the $\mathrm{pH}$ and the temperature every $10 \mathrm{~min}$ and transmitted all data to base stations, which were installed in the barn and milking parlor before commencement of the experiment. Daily mean, minimum, and maximum $\mathrm{pH}$ as well as the time $(\mathrm{min} / \mathrm{d})$ below a threshold of $\mathrm{pH} 5.8$ were calculated per cow and day to determine SARA. Furthermore, the SARA index was analyzed by taking into account the area under $\mathrm{pH} 5.8$ $(5.8-\mathrm{pH} \times \min )$ related to DMI (Penner et al., 2009).

\section{Measurement of Chewing Activity}

The chewing and drinking behaviors were measured on each cow from 0000 to $2359 \mathrm{~h}$ on 3 consecutive days during the baseline ( $\mathrm{d}-1$ to -3 ), adaptation ( 11 to 13), and sampling (d 25 to 27) periods using nosebandsensor halters (RumiWatch System, ITIN + Hoch $\mathrm{GmbH}$, Liestal, Switzerland). The rumination halters were evaluated in detail by Kröger et al. (2016). Data comprised the duration of eating, ruminating, and total 
chewing (eating + ruminating times; $\mathrm{min} / \mathrm{d}$ ) as well as the number of ruminating boli (no./d), chews per bolus (no./bolus), drinking time ( $\mathrm{min} / \mathrm{d}$ ), and drinking gulps (no./d). Additionally, the chewing indices for each chewing category were calculated using data of chewing and feed intake of the same day $(\mathrm{min} / \mathrm{kg}$ of DMI, NDF, and peNDF intake).

\section{Statistical Analyses}

Statistical analyses were performed by ANOVA using the MIXED procedure of SAS (version 9.4, SAS Institute Inc., Cary, NC). All statistical models were conducted with diet (CON, 15\% BP, and 30\% BP), day, and a possible interaction between diet and day as fixed effects. Additionally, for blood metabolites, diurnal $\mathrm{pH}$ and DMI, the time of the day (hour), and the interaction between diet and hour as well as 3-way interactions between diet, day, and hour were considered. The lactation number, individual cow, and experimental run were considered random effects. Measures taken on the same cow but at different times within a group were considered repeated measurements with a first-order autoregressive variance-covariance structure. Degrees of freedom were tested with the method of Kenward-Roger. The measurements taken during the baseline were used as covariates. Furthermore, linear and quadratic effects of BP inclusion level were tested using the CONTRAST option of SAS. For all statistical models, only measurements during the sampling period were considered. The significance level was set at $P \leq$ 0.05 and a tendency at $0.05<P \leq 0.10$.

\section{RESULTS}

\section{Shifts in the Nutrient Profile of Experimental Diets}

The chemical composition of the experimental diets is summarized in Table 1. The addition of BP resulted in major shifts of the energy precursors in the diet. Accordingly, there were numerical changes due to the $\mathrm{BP}$ addition to the diet at $30 \%$ of DM. Compared with CON, a decrease in the content of starch (23.6 vs. $21.4 \%$ ), NDF (34.5 vs. $31.0 \%$ ), and peNDF $_{>1.18}$ (34.4 vs. $31.3 \%$ ) but an increase in the concentration of sugar (4.50 vs. $5.97 \%)$ and EE (4.00 vs. $2.40 \%)$ was observed. Overall, increasing the inclusion rate of $\mathrm{BP}$ in the diets from 0,15 , and $30 \%$ enriched lipogenic precursors such as EE and decreased glucogenic nutrients such as starch in the diet. Other changes in the nutrient profile in response to a $30 \% \mathrm{BP}$ addition was a slightly higher $\mathrm{CP}$ content (15.9 vs. $16.7 \%)$ and a greater sodium concentration (0.8 vs. $2.2 \mathrm{~g} / \mathrm{kg}$ of DM) compared with CON.

\section{Feed Intake, Milk Production, and Composition}

The overall analysis of feed intake showed that total DMI of cows fed BP was greater than that of cows in the CON group $(P<0.01)$, but increasing the BP inclusion from 15 to $30 \%$ did not further increase the DMI (Table 3). The DMI was also affected by the interaction between diet and the measurement day $(P$ $=0.02$, Figure $1 \mathrm{~A})$. Figure $1 \mathrm{~B}$ shows that cows had the highest DMI at $1500 \mathrm{~h}$, when fresh-mixed feed was offered. The DMI increased after milking, whereby the DMI was greater after afternoon milking (1800 h) compared with morning milking $(0730 \mathrm{~h})$. Furthermore, we observed a peak in DMI at $0500 \mathrm{~h}$. Thus, the DMI was affected by the time of day (hour) as well as by the interaction between diet and hour $(P<0.01)$. As shown in Table 3, an increased concentration of BP in the diets increased the daily milk yield and ECM production in a linear fashion $(P<0.01)$. Cows in the $30 \%$ BP group produced $4.5 \mathrm{~kg}$ more milk per day than cows in the CON group.

The composition of milk was also affected by BP. We observed a tendency in which the milk fat content linearly increased by feeding BP and the milk protein linearly decreased ( $P=0.09$ and $P=0.1$, respectively). The ratio of fat to protein increased linearly with increasing $\mathrm{BP}(P=0.03)$. The concentration of MUN linearly decreased with increasing BP contents in feed $(P<0.01)$. The concentrations of lactose and SCC as well as the milk $\mathrm{pH}$ were not affected by BP. Yield of milk protein declined $(P=0.05)$, but other component yield measures were not affected by diet (Table 3 ).

\section{Reticuloruminal $\mathrm{pH}$}

The data of ruminal $\mathrm{pH}$ revealed that the diurnal $\mathrm{pH}$ profile was affected by the time of day, the diet, and their interaction $(P<0.01)$. Figure 2 shows the diurnal ruminal $\mathrm{pH}$ changes in cows fed CON, $15 \% \mathrm{BP}$, and $30 \%$ BP. The reticuloruminal $\mathrm{pH}$ was highest $(\mathrm{pH}$ 6.0-6.2) before morning feeding around $0500 \mathrm{~h}$ and reached its nadir ( $\mathrm{pH} 5.7-5.8$ ) around $2100 \mathrm{~h}$. Cows fed $15 \% \mathrm{BP}$ showed overall the highest $\mathrm{pH}$, whereas cows fed $30 \%$ $\mathrm{BP}$ were in between. The daily mean $\mathrm{pH}$ in the reticulorumen showed a tendency for a quadratic effect $(P=$ $0.06)$. However, the reticuloruminal $\mathrm{pH}$ below $\mathrm{pH} 5.8$ of cows fed CON was $188 \mathrm{~min} / \mathrm{d}$ longer compared with cows fed $15 \%$ BP, indicating a greater risk of SARA. Indeed, as shown in Table 4, the BP had a quadratic effect on the minimum $\mathrm{pH}$, the time in which the $\mathrm{pH}$ was below 5.8, and the SARA index pH $5.8(P \leq 0.01)$. The calculated SARA index of $\mathrm{pH} 5.8$ was lowest in the $15 \%$ BP (3.23) and 30\% BP (4.02) groups and highest in the CON group (5.88). 
Table 3. Dry matter intake, milk yield, and milk composition in dairy cows fed diets not containing (CON) or containing 15 or $30 \%$ bakery by-products (BP)

\begin{tabular}{|c|c|c|c|c|c|c|}
\hline \multirow[b]{2}{*}{ Item } & \multicolumn{3}{|c|}{ Diet } & \multirow[b]{2}{*}{ SEM } & \multicolumn{2}{|c|}{$P$-value } \\
\hline & $\mathrm{CON}$ & $15 \% \mathrm{BP}$ & $30 \% \mathrm{BP}$ & & Linear & Quadratic \\
\hline Overall DMI $(\mathrm{kg} / \mathrm{d})$ & 23.0 & 24.7 & 24.9 & 0.81 & $<0.01$ & 0.17 \\
\hline Milk yield $(\mathrm{kg} / \mathrm{d})$ & 30.6 & 32.1 & 35.1 & 0.79 & $<0.01$ & 0.41 \\
\hline $\operatorname{ECM}^{1}(\mathrm{~kg} / \mathrm{d})$ & 29.4 & 31.5 & 34.3 & 0.98 & $<0.01$ & 0.77 \\
\hline Feed efficiency ${ }^{2}$ & 0.619 & 0.610 & 0.651 & 0.0247 & 0.38 & 0.40 \\
\hline Energy balance (MJ of $\mathrm{NE}_{\mathrm{L}} / \mathrm{d}$ ) & 15.7 & 21.2 & 15.4 & 6.32 & 0.97 & 0.32 \\
\hline BW change $(\%)$ & 3.63 & 3.15 & 4.27 & 0.644 & 0.75 & 0.32 \\
\hline BW change (kg) & 28.0 & 24.9 & 31.3 & 5.12 & 0.86 & 0.46 \\
\hline \multicolumn{7}{|l|}{ Milk constituents } \\
\hline Fat $(\%)$ & 3.59 & 3.75 & 3.90 & 0.165 & 0.09 & 0.97 \\
\hline Protein $(\%)$ & 3.63 & 3.64 & 3.51 & 0.069 & 0.10 & 0.24 \\
\hline Lactose $(\%)$ & 4.73 & 4.67 & 4.67 & 0.036 & 0.22 & 0.55 \\
\hline MUN (mg/dL) & 27.1 & 23.8 & 20.2 & 1.88 & $<0.01$ & 0.93 \\
\hline $\mathrm{SCC}\left(\right.$ cells $\left./ \mathrm{mL} \times 10^{3}\right)$ & 68.2 & 58.5 & 73.1 & 20.09 & 0.74 & 0.31 \\
\hline Fat:protein ratio & 1.01 & 1.03 & 1.09 & 0.040 & 0.03 & 0.51 \\
\hline Fat yield $(\mathrm{kg} / \mathrm{d})$ & 1.16 & 1.23 & 1.29 & 0.065 & 0.18 & 0.95 \\
\hline Protein yield (kg/d) & 1.20 & 1.20 & 1.14 & 0.035 & 0.05 & 0.27 \\
\hline Lactose yield $(\mathrm{kg} / \mathrm{d})$ & 1.56 & 1.54 & 1.54 & 0.012 & 0.17 & 0.60 \\
\hline Milk pH & 6.54 & 6.53 & 6.53 & 0.026 & 0.74 & 0.80 \\
\hline
\end{tabular}

${ }^{1}$ Calculated as $(0.38 \times$ milk fat $\%+0.21 \times$ milk protein $\%+0.95) \times \mathrm{kg}$ of milk $/ 3.2(\mathrm{GfE}, 2001)$.

${ }^{2}$ Calculated as $\mathrm{NE}_{\mathrm{L}}$ output/ $\mathrm{NE}_{\mathrm{L}}$ input.

\section{Chewing Activities and Sorting Behavior}

A tendency toward a linear effect of BP inclusion level revealed longer duration of eating time per kilogram of NDF intake in cows fed BP compared with CON $(P=$ 0.07; Table 5). The time spent eating related to peNDF intake increased linearly with increasing $\mathrm{BP}(P=0.01)$. The total eating time was not affected by the inclusion of $\mathrm{BP}(P=0.14)$.

The minutes of ruminating related to kilograms of peNDF intake tended to increase linearly by increasing $\mathrm{BP}$ in the diet $(P=0.06)$. Feeding $\mathrm{BP}$ had a quadratic effect on the number of ruminating chews per bolus $(P$ $=0.05$ ). However, we found no effect of BP in total regarding the overall ruminating time per day.

The duration of total chewing per kilogram of peNDF intake was linearly affected by the inclusion of $\mathrm{BP}(P$ $<0.01$ ). Similar to the results of total eating and ruminating time, the total chewing time per day also was not affected by dietary treatment. The drinking time and the amount of drinking gulps per day were not affected by the inclusion of BP. Cows sorted for large particles and against fine particles (Supplemental Table S1, https://doi.org/10.3168/jds.2020-18425), and there was a tendency to sort in favor of medium particles in cows fed $\mathrm{BP}(P=0.06)$.

\section{Blood Metabolic Profile}

Diurnal changes in concentrations of selected blood metabolites are shown in Figure 3, whereas the blood variables measured before feeding are shown in Supple- mental Table S2 (https://doi.org/10.3168/jds.2020 -18425). Overall data demonstrated that increasing the proportion of $\mathrm{BP}$ in the diet tended to linearly increase concentrations of BHB $(P=0.06)$ before feeding and had a linear effect on prefeeding concentrations of NEFA and cholesterol $(P \leq 0.01)$ as well as on postprandial concentrations of glucose, insulin, NEFA, BHB, and cholesterol $(P \leq 0.02)$. The diurnal concentration of glucose linearly declined by feeding BP $(P$ $=0.02)$ and decreased throughout the day $(P<0.01)$. More detailed glucose analyses revealed an effect of the 3 -way interaction between diet, day, and hour $(P<$ $0.01)$ as well as a tendency of the interaction between diet and hour $(P=0.07)$. The measured plasma insulin concentration declined linearly in cows as BP inclusion in diets increased $(P=0.01)$, showing an effect of the hour $(P<0.01)$. Although NEFA and BHB remained at a low level (NEFA $<0.05 \mathrm{mmol} / \mathrm{L} ; \mathrm{BHB}<0.6$ $\mathrm{mmol} / \mathrm{L}$ ), their concentrations throughout the day were linearly increased with increasing inclusion of $\mathrm{BP}$ in the diet $(P \leq 0.01)$. The NEFA were not affected by the time of sampling $(P=0.67)$. The concentration of $\mathrm{BHB}$ was higher in 30\% BP compared with CON 6 and $12 \mathrm{~h}$ after feeding. Therefore, the concentration of BHB was affected by the hour $(P<0.01)$ and by the 3 -way interaction between diet, day, and hour $(P<0.01)$. The strongest effect was observed on cholesterol, showing a linear increase in cows fed BP throughout the experimental period $(P<0.01)$ and being $35 \%$ higher in $30 \%$ BP compared with CON. The BP had a quadratic effect on glutamate dehydrogenase concentration $(P$ $=0.04)$. All other analyzed blood variables measured 

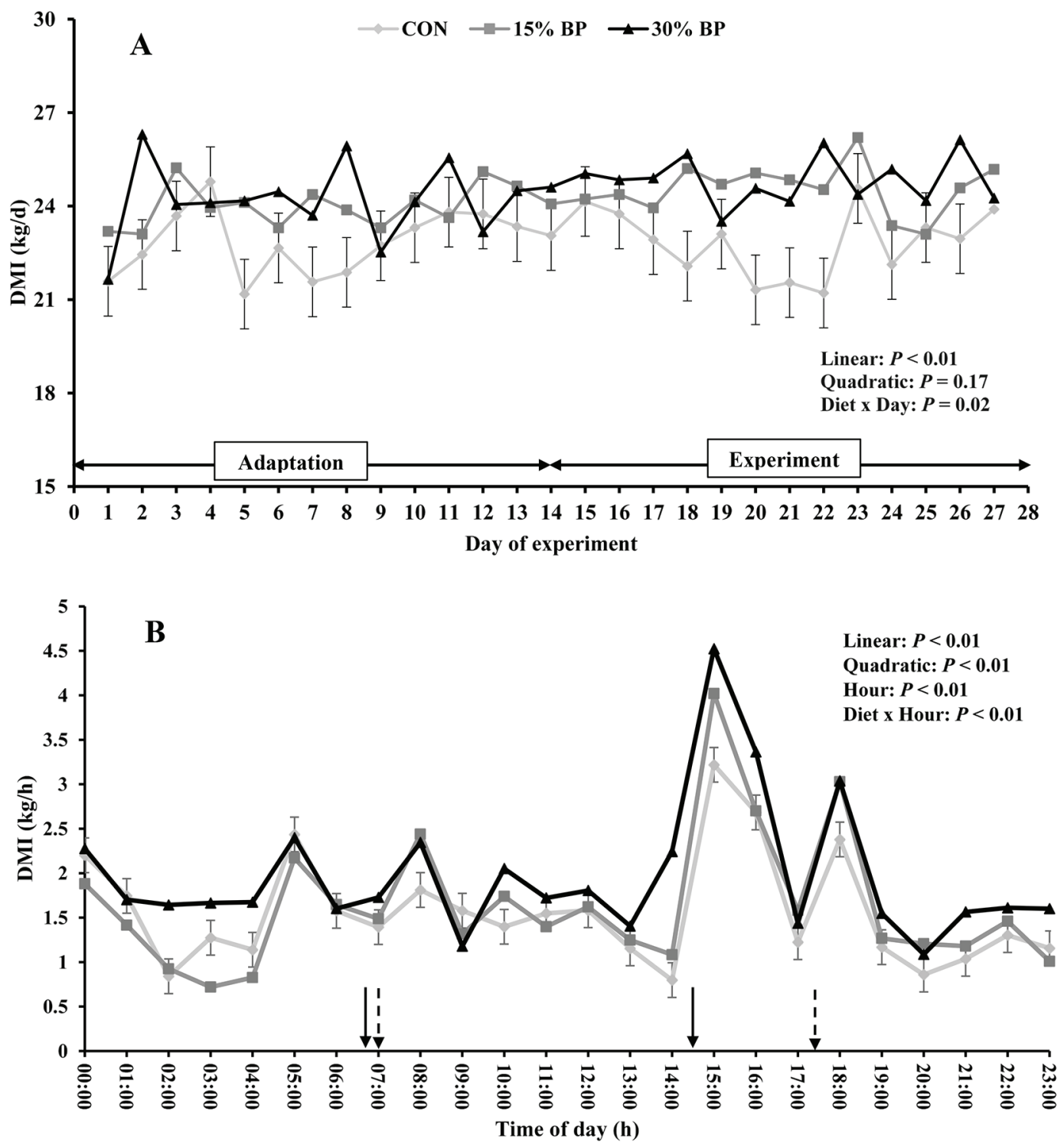

Figure 1. Total DMI (A) and diurnal DMI (B) in cows fed diets not containing (CON) or containing 15 or $30 \%$ bakery by-products (BP). Cows had continuous free access to their feed troughs, interrupted only by the morning (0645-0700 h) and afternoon (1400-1500 h) feedings and the morning $(0700-0730 \mathrm{~h})$ and afternoon $(1730-1800 \mathrm{~h})$ milkings. Dashed arrows indicate milking times, and dark arrows indicate feeding times. The error bars of the control group indicate the SEM of all groups within each time point.

before the morning feeding, such as Hp, liver enzymes (aspartate aminotransferase, $\gamma$-glutamyltransferase), calcium, and phosphorus as well as other metabolites, were not affected by BP (Supplemental Table S2; https: //doi.org/10.3168/jds.2020-18425).

\section{DISCUSSION}

\section{Feed Intake, Performance, and Metabolic Profile}

This research mainly aimed to establish the effects of the graded substitution of cereal grains by BP on DMI, milk yield and composition, metabolic profile, and risk of SARA in dairy cows. The gradual replacement of cereal grains with 50 and $100 \%$ BP led to respective shifts in nutrient profile of the diets. Notably, the sugar and fat contents were higher and starch content was lower in the BP-based diets, resulting in increased lipogenic precursors in these diets, eventually affecting the DMI and the performance of mid-lactation cows in the current study. The increase in sugar content from $4.5 \%$ to roughly $6 \%$ in the $\mathrm{BP}$ diets might have increased the lipogenic factors, as the fermentation of sucrose in the rumen may lead to lipogenic precursors such as 
Table 4. Reticuloruminal $\mathrm{pH}$ and acidosis index in dairy cows fed diets not containing (CON) or containing 15 or $30 \%$ bakery by-products (BP)

\begin{tabular}{|c|c|c|c|c|c|c|}
\hline \multirow[b]{2}{*}{ Item } & \multicolumn{3}{|c|}{ Diet } & \multirow[b]{2}{*}{ SEM } & \multicolumn{2}{|c|}{$P$-value } \\
\hline & $\mathrm{CON}$ & $15 \% \mathrm{BP}$ & $30 \% \mathrm{BP}$ & & Linear & Quadratic \\
\hline Mean pH & 5.91 & 5.98 & 5.93 & 0.037 & 0.79 & 0.06 \\
\hline Minimum $\mathrm{pH}$ & 5.51 & 5.58 & 5.48 & 0.053 & 0.51 & 0.02 \\
\hline Maximum $\mathrm{pH}$ & 6.59 & 6.62 & 6.56 & 0.14 & 0.44 & 0.25 \\
\hline Time $\mathrm{pH}<5.8(\mathrm{~min} / \mathrm{d})$ & 569 & 381 & 498 & 95.9 & 0.17 & $<0.01$ \\
\hline $\mathrm{SD}^{1}$ & 0.264 & 0.255 & 0.261 & 0.056 & 0.84 & 0.60 \\
\hline Area $\mathrm{pH}<5.8(\mathrm{pH} \times \min / \mathrm{d})$ & 123 & 73 & 92 & 21.2 & 0.06 & 0.01 \\
\hline SARA index $\mathrm{pH} 5.8^{2}$ & 5.88 & 3.23 & 4.02 & 0.968 & 0.02 & 0.01 \\
\hline SARA index $(\min \mathrm{pH}<5.8 / \mathrm{kg}$ of DMI $)$ & 27.6 & 16.8 & 22.5 & 3.67 & $<0.01$ & $<0.01$ \\
\hline
\end{tabular}

${ }^{1}$ Standard deviation of measurements within a day.

${ }^{2}$ The area under $\mathrm{pH} 5.8$ related to DMI.

acetate (Razzaghi et al., 2016) or butyrate and less to propionate (Oba et al., 2015), depending on the sucrose inclusion dose in the diet.

The higher DMI due to BP inclusion is an interesting finding of this study and indicates that BP did not impair the palatability of the TMR; rather, its inclusion enhanced the appetite of the cows. The role of increased fat and sugars and decreased starch in the diet on feed intake of dairy cows is often controversially discussed in the literature. Razzaghi et al. (2016) did not observe any change in feed intake of cows when increasing sugar content in place of starch or fat at a higher level of substitution than in this study (around 4\% difference in the TMR), whereas fat supplementation per se typically decreases the DMI in dairy cows (Allen, 2000). However, some studies have indicated that substitution of fat for grain can reduce the hypophagic effects of propionate by reducing its flux to the liver and hence seems to enhance feed intake in dairy cows (Allen, 2000). Propionate was not measured in this study, but the low concentration of systemic glucose suggests lower levels of glucogenic precursors such as ruminal propionate and valerate or less net duodenal glucose supply in the BP cows. Another explanation for the increased DMI with $\mathrm{BP}$ inclusion relates to the altered fat:starch ratio in the $\mathrm{BP}$ diets and the influence on the endocrine regulation

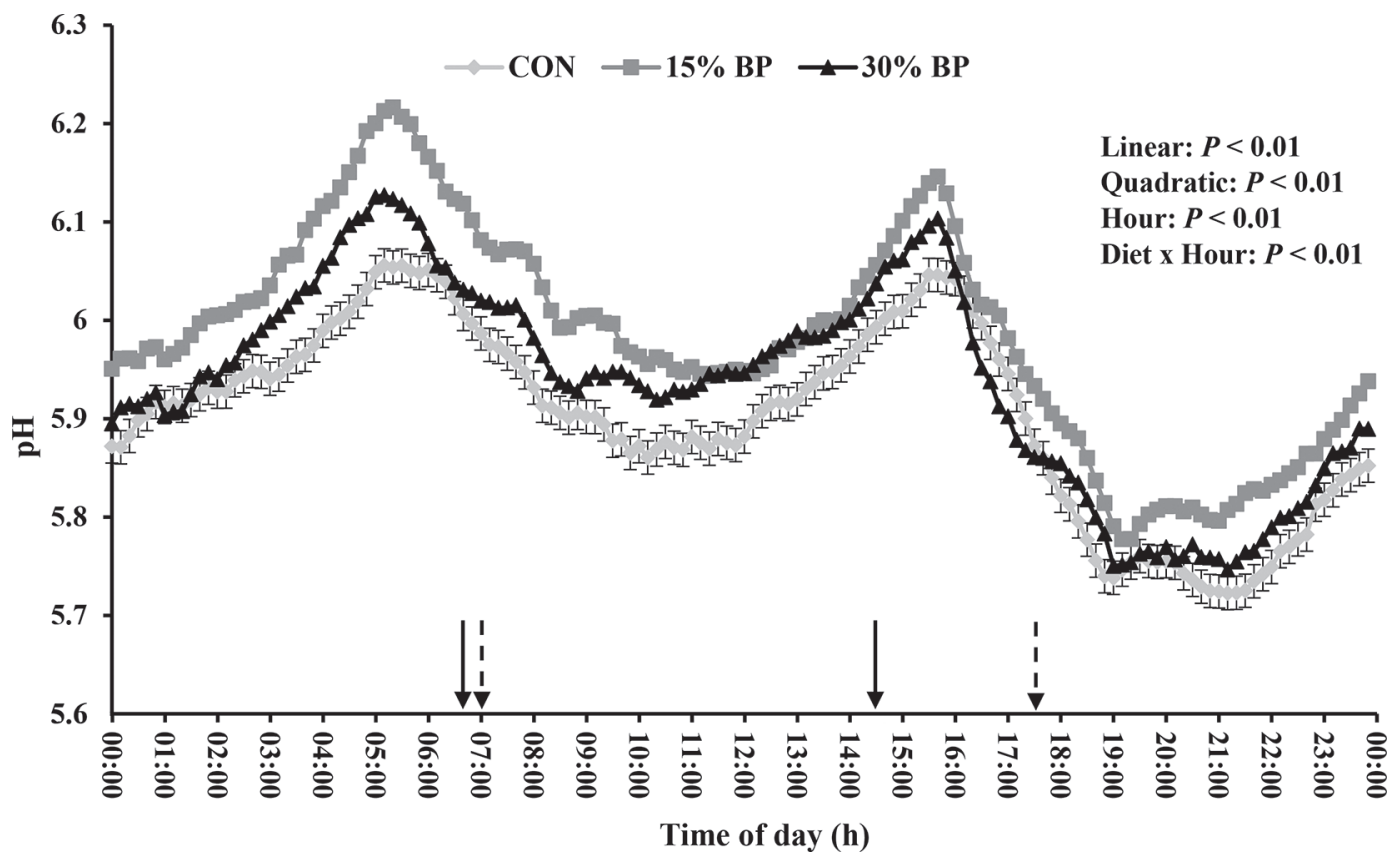

Figure 2. Diurnal pH dynamics in cows fed diets not containing (CON) or containing 15 or $30 \%$ bakery by-products (BP). Cows had continuous free access to their feed troughs, interrupted only by the morning $(0645-0700 \mathrm{~h})$ and afternoon (1400-1500 h) feedings and the morning $(0700-0730 \mathrm{~h})$ and afternoon $(1730-1800 \mathrm{~h})$ milkings. Dashed arrows indicate milking times, and dark arrows indicate feeding times. The error bars of the control group indicate the SEM of all groups within each time point. 
Table 5. Chewing variables in dairy cows fed diets not containing (CON) or containing 15 or $30 \%$ bakery by-products (BP)

\begin{tabular}{|c|c|c|c|c|c|c|}
\hline \multirow[b]{2}{*}{ Item } & \multicolumn{3}{|c|}{ Diet } & \multirow[b]{2}{*}{ SEM } & \multicolumn{2}{|c|}{$P$-value } \\
\hline & $\mathrm{CON}$ & $15 \% \mathrm{BP}$ & $30 \% \mathrm{BP}$ & & Linear & Quadratic \\
\hline \multicolumn{7}{|l|}{ Eating } \\
\hline $\min / \mathrm{d}$ & 276 & 300 & 316 & 42.8 & 0.14 & 0.88 \\
\hline $\mathrm{min} / \mathrm{kg}$ of $\mathrm{DMI}$ & 12.8 & 13.2 & 13.7 & 1.09 & 0.46 & 0.97 \\
\hline $\mathrm{min} / \mathrm{kg}$ of NDF intake & 34.5 & 38.0 & 44.3 & 3.43 & 0.07 & 0.50 \\
\hline $\mathrm{min} / \mathrm{kg}$ of peNDF ${ }^{1}$ intake & 50.7 & 56.0 & 70.1 & 6.20 & 0.01 & 0.44 \\
\hline \multicolumn{7}{|l|}{ Ruminating } \\
\hline $\min / \mathrm{d}$ & 627 & 599 & 605 & 64.8 & 0.24 & 0.27 \\
\hline $\min / \mathrm{kg}$ of DMI & 23.1 & 21.0 & 21.1 & 1.13 & 0.10 & 0.29 \\
\hline $\mathrm{min} / \mathrm{kg}$ of NDF intake & 65.8 & 60.3 & 66.7 & 3.60 & 0.83 & 0.08 \\
\hline $\min / \mathrm{kg}$ of peNDF intake & 91.2 & 88.3 & 104 & 7.14 & 0.06 & 0.09 \\
\hline Ruminating boli (no./d) & 661 & 646 & 650 & 72.3 & 0.57 & 0.56 \\
\hline Ruminating chews (no./bolus) & 54.9 & 49.3 & 51.6 & 4.24 & 0.15 & 0.05 \\
\hline \multicolumn{7}{|l|}{ Total chewing } \\
\hline $\min / \mathrm{d}$ & 822 & 817 & 836 & 23.9 & 0.70 & 0.70 \\
\hline $\min / \mathrm{kg}$ of DMI & 35.8 & 34.3 & 34.5 & 1.80 & 0.51 & 0.61 \\
\hline $\min / \mathrm{kg}$ of NDF intake & 103 & 98.7 & 110 & 5.5 & 0.31 & 0.21 \\
\hline $\min / \mathrm{kg}$ of peNDF intake & 142 & 145 & 173 & 11.25 & 0.01 & 0.18 \\
\hline Drinking $(\min / \mathrm{d})$ & 16.5 & 19.4 & 21.5 & 4.09 & 0.29 & 0.94 \\
\hline Drinking gulps (no./d) & 239 & 312 & 315 & 68.0 & 0.26 & 0.54 \\
\hline
\end{tabular}

${ }^{1}$ Physically effective NDF.

of the feed intake mediated by glucose availability and insulin. Fermentation of starchy grains in the rumen leads mainly to propionate, whereas sugar fermentation increases acetate (Razzaghi et al., 2016) or butyrate formation (Oba et al., 2015) depending on the sugar inclusion rate in the diet, whereby only propionate is used as a glucose precursor. The increase in DMI in $\mathrm{BP}$ diets leveled out the differences in the starch intake among groups, but differences in the ratio of key energy glucogenic and lipogenic precursors between $\mathrm{CON}$ and BP diets such as starch and fat almost doubled (i.e., 9.8 vs. 5.4). More glucose is needed for the formation of oxaloacetate in the major peripheral tissues to facilitate the $\beta$-oxidation of fatty acids (Adewuyi et al., 2005), which results in lower systemic glucose availability and reduced insulin levels in cows fed $\mathrm{BP}$ due to the nutrient shift in BP diets. Because insulin is known to be an important satiety hormone (Allen, 2014), constantly lower insulin levels in the BP cows likely enhanced the appetite in the latter diet, resulting in greater DMI. Cows fed BP diets also had overall higher ruminal $\mathrm{pH}$, and this effect was especially evident in the $15 \% \mathrm{BP}$ group. It is reasonable to assume that an improved rumen health status might also have stimulated the DMI in cows fed the BP diets.

Cows of this study were after the peak of lactation. During this period, dietary supply of $\mathrm{NE}_{\mathrm{L}}$ and nutrients directly affect the rate of milk component synthesis, whereas insulin plays an important regulatory role in the priority use of glucose for milk production and tissue accretion processes (Weiss and Pinos-Rodríguez, 2009; Boerman et al., 2015). Inclusion of BP in the diet increased the calculated $\mathrm{NE}_{\mathrm{L}}$ content of the diet, mainly due to greater fat content, whereas the increase in DMI resulted in an overall increase of $\mathrm{NE}_{\mathrm{L}}$ and nutrient intake in cows fed the BP diets. This increase in energy and nutrient availability resulted in improved milk production performance in cows fed $\mathrm{BP}$ without showing any difference in BW among groups. By feeding the $30 \%$ BP diet, the insulin concentration remained constantly lower during the experiment. Glucose uptake is an insulin-stimulated process in skeletal muscle, heart, and fat tissues, whereas it is insulin independent in the mammary cells (De Koster and Opsomer, 2013). This suggests that the reduced insulin concentration in the $30 \%$ BP diet allowed more glucose to be taken by the mammary cells, resulting in greater milk yields and not in tissue accretion in this group. van Knegsel et al. (2007) observed an increased priority of energy in milk fat production compared with body reserves, resulting in a lower energy balance by feeding a lipogenic diet to dairy cows in early lactation. By this line of thinking, our data suggest that feeding 30\% BP in early-lactation cows might have the potential to aggravate the negative energy balance. However, because DMI and energy intake increased in cows of the $15 \%$ BP group without a clear effect on blood glucose and insulin, replacing grain by only $50 \%$ BP might offer a better compromise for early-lactation cows. Nevertheless, more investigations are needed to confirm this hypothesis.

Another interesting finding was that the milk fat content tended to increase in cows in the $30 \%$ BP group despite a higher milk yield. Milk fat derives from 2 sources: de novo milk fat synthesis using mainly the 

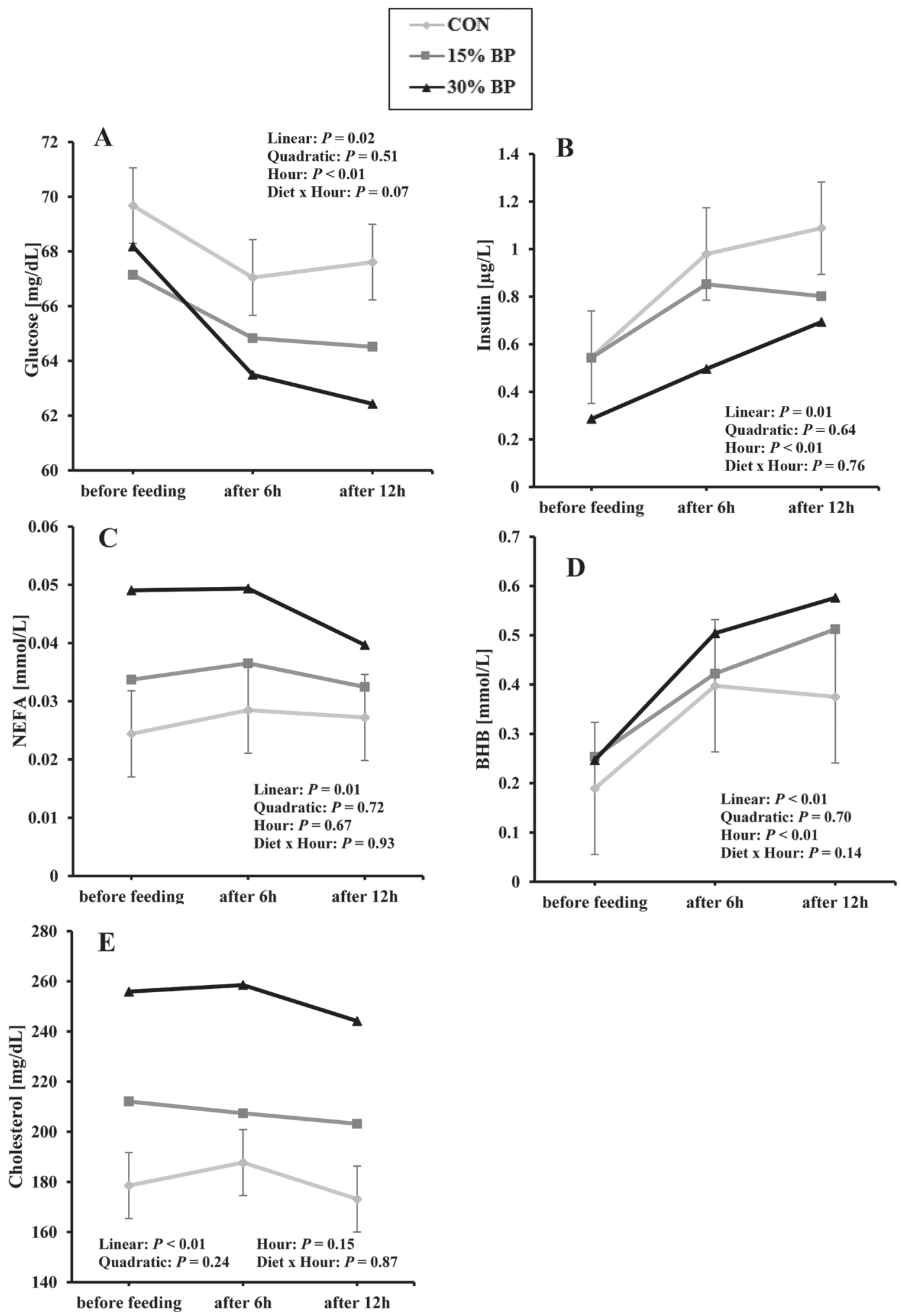

Figure 3. Postprandial serum concentrations of glucose (A), insulin (B), nonesterified fatty acids (NEFA; C), BHB (D), and cholesterol (E) on d 21 and 28 at 3 times of sampling (before feeding and 6 and $12 \mathrm{~h}$ after feeding) in cows fed diets not containing (CON; (ם) or $30 \%(\boldsymbol{\Lambda})$ bakery by-products (BP). The error bars of the control group indicate the SEM of all groups within each time point. 
SCFA acetate and butyrate as precursors and the already synthesized fatty acids from the feed and rumen microbes or the body fat in early lactation (as reviewed by Bauman and Griinari, 2003). Due to the higher sugar content in diets containing $\mathrm{BP}$ and the increased concentrations of $\mathrm{BHB}$ and cholesterol in cows of the $\mathrm{BP}$ group, we assume that the availability of ruminal acetate and butyrate increased, which might have contributed to an increased de novo fatty acid synthesis (Martel et al., 2011; Razzaghi et al., 2016). On the other hand, the BP had a higher fat content deriving mainly from oilseeds in bakery products rich in unsaturated long-chain fatty acids (Humer et al., 2018a). Feeding BP diets likely enhanced the flow of fatty acids to the duodenum, either SFA or incorporated into the microbial biomass, which in turn increased the systemic viability of preformed fatty acids transported as verylow-density lipoprotein in the milk. In addition, the higher ruminal $\mathrm{pH}$ in cows fed $\mathrm{BP}$ might have played a further role regarding milk fat production. It is well known that a decrease in ruminal $\mathrm{pH}$ inhibits milk fat synthesis, resulting in milk fat depression (Danscher et al., 2015; Humer et al., 2018b). Cows in the $30 \%$ BP group tended to produce milk with lower protein contents compared with the other groups. Some other studies have shown the importance of glucose and insulin as modulators of milk protein synthesis by infusing starch, glucose, and propionate, thereby increasing milk protein content (Rigout et al., 2003; Rius et al., 2010). The reduction in plasma glucose concentration in cows fed $30 \%$ BP suggests that AA might be increasingly used in the liver for gluconeogenesis, hence lacking for milk protein synthesis; due to the low insulin level in the $30 \%$ BP group, a stimulator for milk protein synthesis is missing (Molento et al., 2002; De Koster and Opsomer, 2013; Winkelman and Overton, 2013). Thus, the decline in milk protein yield in the $30 \% \mathrm{BP}$ group might have been caused by a lack of glucogenic precursors in this diet. In contrast to Weiss and PinosRodríguez (2009), who showed an increase in MUN by supplementing dietary fat, we observed a linear decrease in MUN, although still within normal ranges. Diets of this study were isonitrogenous and isoenergetic (about $24 \mathrm{~g}$ of $\mathrm{CP} / \mathrm{MJ}$ of $\mathrm{NE}_{\mathrm{L}}$ ), which suggests that the availability of protein was not the reason for differences in MUN among diets. However, the higher sugar content might have provided more rapid energy for ammonia utilization by rumen microbes in the BP diets, hence lowering ruminal ammonia concentrations (França et al., 2012; Humer et al., 2018a) and ultimately MUN. Another reason might also be a decreased protein degradability in the rumen due to baking in the BP, as described by Humer et al. (2018a), which might have decreased the rumen-degradable protein fraction compared with CON.

Changes in the nutrient profile in the diet had marked influence on the blood metabolic profile of cows receiving BP. Although the concentration of overall plasma glucose was high, cows receiving BP had lower concentrations of glucose compared with CON cows, which decreased throughout the day. As mentioned before, the inclusion of BP likely resulted in a reduced formation of propionate in the rumen. Because propionate is the main precursor of glucose production via hepatic gluconeogenesis, the glucose concentration is reduced in the blood as the proportion of BP in the diet increases. Accordingly, Oba and Allen (2003) also observed a reduction of propionate, glucose, and insulin due to lowstarch diets containing $21.2 \%$ (of DM) starch, which is similar to the starch content in our $30 \% \mathrm{BP}$ diet. The reduction in the glucose concentration $6 \mathrm{~h}$ after feeding, regardless of diet, is attributed to the activity of increasing insulin concentrations, which inhibits gluconeogenesis and stimulates glycogen synthesis in the liver and muscles (Oba and Allen, 2003). The decrease of glucose and insulin by increasing the BP content in the diet was associated with linear elevation of plasma NEFA and BHB. Despite this increase, looking at the absolute levels, concentrations of NEFA and BHB were low in the current study (NEFA: $0.024-0.049 \mathrm{mmol} / \mathrm{L}$; BHB: $0.18-0.58 \mathrm{mmol} / \mathrm{L}$ ). The higher fat content probably led to an increase in NEFA, as previous studies have also described (Grummer and Carroll, 1991; Grummer, 2008; Bernard et al., 2009), and the augmentation of NEFA and the lack of oxaloacetate might have caused an increase in the formation of BHB in the liver (Adewuyi et al., 2005). Another plausible assumption of the postprandial increase of BHB in cows fed BP diets is the higher sugar content, which may have resulted in higher rates of butyrate formation in the rumen (Kopečný et al., 2003; Oba et al., 2015). Butyrate is rapidly metabolized to BHB in the ruminal epithelial cells, which might have also caused the elevation of BHB level in the blood (Bergman, 1990; Liu et al., 2019). Both NEFA and BHB provide ruminants energy in the absence of glucose precursors (Adewuyi et al., 2005).

Another interesting finding of this research was the high cholesterol concentration, which ranged from 173 to $258 \mathrm{mg} / \mathrm{dL}$. In particular, cows in the $30 \% \mathrm{BP}$ group had the highest cholesterol content, with an increment of $35 \%$ compared with cows in the CON group. Ruminant diets are free of cholesterol, which is endogenously synthesized using glucose and acetate as the main sources for cholesterol biosynthesis, whereby the use of acetate predominates (Liepa et al., 1978). Because the systemic 
glucose level was lower with BP diets, the higher cholesterol level in these cows could have occurred because of an enhanced availability of acetyl CoA precursors in the BP diets. Thus, the acetyl CoA supply exceeds the oxaloacetate availability in the tricarboxylic acid cycle, which in turn leads to an increased esterification of acetyl CoA to triacylglycerides (van Knegsel et al., 2005; Kessler et al., 2014). The cholesterol levels in mid-lactation cows are orchestrated from the needs for total cholesterol, whereby higher triacylglycerides in the liver and a higher proportion of long-chain fatty acids reaching the small intestine increase the need for very-low-density lipoprotein cholesterol, which has also been observed in several other studies (Douglas et al., 2004; Bernard et al., 2009; Razzaghi et al., 2016). Higher plasma cholesterol concentrations are associated with enhanced milk yield as well as improved fertility by increasing the likelihood of conception and estrus development during first ovulation (Kweon et al., 1986; Westwood et al., 2002).

\section{Rumen Acidosis and Chewing Behavior}

The second aim of our study was to evaluate the influence of $\mathrm{BP}$ on rumen health combined with monitoring the eating and ruminating behaviors of the cows. Because of nutrient profile shifts, particularly decreasing fiber and starch and increasing sugars and a potential increase of starch digestibility, we hypothesized that feeding $30 \% \mathrm{BP}$ in the diet might increase the risk of SARA. The measurements regarding ruminal fermentation patterns revealed rather surprising results. Data analyzed to characterize the diurnal ruminal $\mathrm{pH}$ showed that CON cows spent more minutes per day in which ruminal $\mathrm{pH}$ remained $<5.8$ compared with BP cows. Furthermore, the calculated area under $\mathrm{pH}$ $<5.8$ and SARA index of $\mathrm{pH}<5.8$ were greater in $\mathrm{CON}$ cows, which indicates a greater risk for SARA in CON cows (Macmillan et al., 2017). Our results showed that $15 \%$ BP cows had the lowest odds for developing SARA, followed by $30 \% \mathrm{BP}$ cows. At first sight this is rather surprising because the peNDF content decreased by increasing the levels of $\mathrm{BP}$ in the diets. The peNDF content in the diet is the main determinant of the ruminal pH (Zebeli et al., 2006). However, increasing the $\mathrm{BP}$ levels in the diet lowered the amount of starch from roughly 24 to $21 \%$. As reviewed by Zebeli et al. (2012), an average amount of $31.2 \% \mathrm{peNDF}_{>1.18 \mathrm{~mm}}$ and $18.5 \%$ peNDF $_{>8 \mathrm{~mm}}$ is recommended in the diet to prevent SARA, with starch content of approximately $20 \%$. Our diets contained on average 31.3 to $34.4 \%$ peNDF $_{>1.18 \mathrm{~mm}}$ and 20.4 to $24.4 \%$ peNDF $_{>8 \mathrm{~mm}}$, which is within the recommended range but with higher starch contents than recommended, especially in the CON diet (24\%).
Therefore, the longer period in which the $\mathrm{pH}$ is below 5.8 and higher acidosis index in cows fed CON might be due to the increased starch content, which has exceeded the relatively high peNDF content. In addition, the grain fraction in the CON diet consisted of wheat and triticale, which have high ruminal starch degradability (Offner et al., 2003; Benninghoff et al., 2015), and this might also have lessened the buffering capacity of the rumen. Highly fermentable starchy grains are rapidly fermented to SCFA in the rumen, which in turn leads to an accumulation of protons, causing a reduction of ruminal pH. A large proportion of SCFA is absorbed via the rumen epithelium, which is an important process in preventing SARA (Aschenbach et al., 2011). The degree of SCFA absorption depends on the size and density of the papillae (Van Soest, 1994), whereby butyrate has been reported to act as an important stimulator of the ruminal epithelium development (Liu et al., 2019). Thus, feeding BP might stimulate the growth of the ruminal epithelium, allowing a greater absorption of SCFA, which would explain the higher ruminal $\mathrm{pH}$ in cows fed $\mathrm{BP}$. The $\mathrm{pH}$ in the rumen responds very sensitively to meals and chewing activity; $\mathrm{pH}$ decreases after feeding and recovers slowly during rumination (Allen, 1997). The relation between $\mathrm{pH}$ and DMI is also evident in the current study.

The BP did not affect the total rumination time per day; however, we observed a tendency for a linear decrease in ruminating time per DMI and for an increase in time spent ruminating per kilogram of peNDF with the inclusion of BP. The cows in the BP groups had a higher DMI, but their rations contained less peNDF, which might lead to the reduced ruminating time. The longer ruminating duration per kilogram of DMI in CON might have been an attempt to promote saliva production for neutralizing their ruminal $\mathrm{pH}$ (Allen, 1997; Beauchemin et al., 2003).

\section{CONCLUSIONS}

This study showed that the substitution of grains by BP potentially shifted the nutrient profile from glucogenic to lipogenic. This effect was associated with enhancement of feed intake and milk production as well as major changes in the metabolic profile and stabilization of ruminal $\mathrm{pH}$. However, the responses obtained differed based on the level of BP inclusion. Accordingly, feeding $15 \%$ enabled high DMI level but with high levels of glucose, insulin, and cholesterol, and reduced the risk of SARA. On the other hand, feeding 30\% BP increased DMI and resulted in higher milk energy production but significantly lowered blood glucose and insulin levels. Feeding up to $30 \%$ BP brings several benefits to substitute grains in mid-lactation cows. Because of positive 
effects on feed intake and energy metabolism, our data may also suggest advantages to feeding $15 \%$ BP in the diets of early-lactation cows.

\section{ACKNOWLEDGMENTS}

A. Kaltenegger was supported by a scholarship from the H. Wilhelm Schaumann Stiftung (Hamburg, Germany), which is highly acknowledged. The authors thank A. Pieler and R. Retsch from Königshofer Futtermittel GmbH (Ebergassing, Austria) for the supply of bakery products and preparation of the concentrate feeds for the experiment. We also thank W. Knaus (Department of Sustainable Agricultural Systems, Division of Livestock Sciences, University of Natural Resources and Life Sciences in Vienna, Austria) for providing the RumiWatch rumination halters (RumiWatch System, ITIN + Hoch GmbH, Liestal, Switzerland) that were used for the experiment. We are grateful to E. Draxler and J. Huber (Dairy Research vetFarm Kremesberg, Pottenstein, Austria) and T. Enzinger (Institute of Animal Nutrition and Functional Plant Compounds at Vetmeduni, Vienna, Austria) for their excellent support during the experiment. We thank S. Leiner and A. Dockner (Institute of Animal Nutrition and Functional Plant Compounds at Vetmeduni, Vienna) for their assistance in laboratory analyses and the staff of the laboratory of the Central Clinical Pathology Unit (Vetmeduni, Vienna) for blood analyses as well as the Qualitätslabor Niederösterreich (Gmünd, Austria) for milk analyses. The authors have not stated any conflicts of interest.

\section{REFERENCES}

Adewuyi, A. A., E. Gruys, and F. J. C. M. van Eerdenburg. 2005. Non esterified fatty acids (NEFA) in dairy cattle. A review. Vet. Q. 27:117-126. https://doi.org/10.1080/01652176.2005.9695192.

Allen, M. S. 1997. Relationship between fermentation acid production in the rumen and the requirement for physically effective fiber. J. Dairy Sci. 80:1447-1462. https://doi.org/10.3168/jds.S0022 -0302(97) 76074-0.

Allen, M. S. 2000. Effects of diet on short-term regulation of feed intake by lactating dairy cattle. J. Dairy Sci. 83:1598-1624. https:// doi.org/10.3168/jds.S0022-0302(00)75030-2.

Allen, M. S. 2014. Drives and limits to feed intake in ruminants. Anim. Prod. Sci. 54:1513-1524. https://doi.org/10.1071/AN14478.

Aschenbach, J. R., G. B. Penner, F. Stumpff, and G. Gäbel. 2011. Ruminant nutrition symposium: Role of fermentation acid absorption in the regulation of ruminal pH. J. Anim. Sci. 89:1092-1107. https: //doi.org/10.2527/jas.2010-3301.

Bauman, D. E., and J. M. Griinari. 2003. Nutritional regulation of milk fat synthesis. Annu. Rev. Nutr. 23:203-227. https://doi.org/ 10.1146/annurev.nutr.23.011702.073408.

Beauchemin, K. A., W. Z. Yang, and L. M. Rode. 2003. Effects of particle size of alfalfa-based dairy cow diets on chewing activity, ruminal fermentation, and milk production. J. Dairy Sci. 86:630-643. https://doi.org/10.3168/jds.S0022-0302(03)73641-8.

Benninghoff, J., M. Paschke-Beese, and K. H. Südekum. 2015. In situ and in vitro ruminal degradation of maize grain and untreated or xylose-treated wheat, barley and rye grains. Anim. Feed Sci. Technol. 210:86-93. https://doi.org/10.1016/j.anifeedsci.2015.10.002.

Bergman, E. N. 1990. Energy contributions of volatile fatty acids from the gastrointestinal tract in various species. Physiol. Rev. 70:567590. https://doi.org/10.1152/physrev.1990.70.2.567.

Bernard, L., M. Bonnet, C. Leroux, K. J. Shingfield, and Y. Chilliard. 2009. Effect of sunflower-seed oil and linseed oil on tissue lipid metabolism, gene expression, and milk fatty acid secretion in Alpine goats fed maize silage-based diets. J. Dairy Sci. 92:6083-6094. https://doi.org/10.3168/jds.2009-2048.

Boerman, J. P., S. B. Potts, M. J. VandeHaar, and A. L. Lock. 2015. Effects of partly replacing dietary starch with fiber and fat on milk production and energy partitioning. J. Dairy Sci. 98:7264-7276. https://doi.org/10.3168/jds.2015-9467.

Bradford, G. E. 1999. Contributions of animal agriculture to meeting global human food demand. Livest. Prod. Sci. 59:95-112. https:// doi.org/10.1016/S0301-6226(99)00019-6.

Danscher, A. M., S. Li, P. H. Andersen, E. Khafipour, N. B. Kristensen, and J. C. Plaizier. 2015. Indicators of induced subacute ruminal acidosis (SARA) in Danish Holstein cows. Acta Vet. Scand. 57:39. https://doi.org/10.1186/s13028-015-0128-9.

De Koster, J. D., and G. Opsomer. 2013. Insulin resistance in dairy cows. Vet. Clin. North Am. Food Anim. Pract. 29:299-322. https: //doi.org/10.1016/j.cvfa.2013.04.002.

Douglas, G. N., T. R. Overton, H. G. Bateman II, and J. K. Drackley. 2004. Peripartal metabolism and production of Holstein cows fed diets supplemented with fat during the dry period. J. Dairy Sci 87:4210-4220. https://doi.org/10.3168/jds.S0022-0302(04)73566 $-3$.

Drouillard, J. 2016. Grain processing for ruminants: Improving health, performance, carcass quality, and meat composition. Pages $1-5$ in 15. BOKU-Symposium Tierernährung. Accessed Jul. 2020. https://boku.ac.at/fileadmin/data/H03000/H97000/H97600/ Symptagungsbaende/BOKU_Symposium_2016.pdf.

Eastridge, M. L. 2006. Major advances in applied dairy cattle nutrition. J. Dairy Sci. 89:1311-1323. https://doi.org/10.3168/jds .S0022-0302(06)72199-3.

Ertl, P., Q. Zebeli, W. Zollitsch, and W. Knaus. 2016. Feeding of wheat bran and sugar beet pulp as sole supplements in high-forage diets emphasizes the potential of dairy cattle for human food supply. J. Dairy Sci. 99:1228-1236. https://doi.org/10.3168/jds.2015 -10285 .

França, A. B., M. J. F. Morenz, F. C. F. Lopes, A. S. Madeiro, D. A. Morenz, B. M. Faria, L. S. Cabral, and C. E. M. Fonseca. 2012. Bakery waste in sheep diets: Intake, digestibility, nitrogen balance and ruminal parameters. Rev. Bras. Zootec. 41:147-153. https:// doi.org/10.1590/S1516-35982012000100022.

GfE. 2001. Recommendations for the Supply of Energy and Nutrients to Dairy Cows and Heifers. Committee for Requirement Standards of the Society of Nutrition Physiology (in German). DLG-Verlag, Frankfurt am Main, Germany.

Grummer, R. R. 2008. Nutritional and management strategies for the prevention of fatty liver in dairy cattle. Vet. J. 176:10-20. https:/ /doi.org/10.1016/j.tvjl.2007.12.033.

Grummer, R. R., and D. J. Carroll. 1991. Effects of dietary fat on metabolic disorders and reproductive performance of dairy cattle. J. Anim. Sci. 69:3838-3852. https://doi.org/10.2527/1991.6993838x.

Hetherington, R. F., and G. L. Krebs. 2002. The use of bakery wastes in feedlot rations for sheep. Proc. Aust. Soc. Anim. Prod. 24:89-92.

Humer, E., S. Aditya, A. Kaltenegger, F. Klevenhusen, R. M. Petri, and Q. Zebeli. 2018a. Graded substitution of grains with bakery by-products modulates ruminal fermentation, nutrient degradation, and microbial community composition in vitro. J. Dairy Sci. 101:3085-3098. https://doi.org/10.3168/jds.2017-14051.

Humer, E., J. R. Aschenbach, V. Neubauer, I. Kröger, R. Khiaosa-ard, W. Baumgartner, and Q. Zebeli. 2018b. Signals for identifying cows at risk of subacute ruminal acidosis in dairy veterinary practice. J. Anim. Physiol. Anim. Nutr. (Berl.) 102:380-392. https:// doi.org/10.1111/jpn.12850.

Humer, E., and Q. Zebeli. 2017. Grains in ruminant feeding and potentials to enhance their nutritive and health value by chemical pro- 
cessing. Anim. Feed Sci. Technol. 226:133-151. https://doi.org/10 $.1016 /$ j.anifeedsci.2017.02.005.

Kessler, E. C., J. J. Gross, R. M. Bruckmaier, and C. Albrecht. 2014 Cholesterol metabolism, transport and hepatic regulation in dairy cows during transition and early lactation. J. Dairy Sci. 97:54815490. https://doi.org/10.3168/jds.2014-7926.

Klevenhusen, F., P. Pourazad, S. U. Wetzels, M. Qumar, A. Khol-Parisini, and Q. Zebeli. 2014. Technical note: Evaluation of a real-time wireless $\mathrm{pH}$ measurement system relative to intraruminal differences of digesta in dairy cattle. J. Anim. Sci. 92:5635-5639. https: //doi.org/10.2527/jas.2014-8038.

Kononoff, P. J., A. J. Heinrichs, and D. R. Buckmaster. 2003. Modification of the Penn State forage and total mixed ration particle separator and the effects of moisture content on its measurements. J. Dairy Sci. 86:1858-1863. https://doi.org/10.3168/jds.S0022 -0302(03)73773-4.

Kopečný, J., M. Zorec, J. Mrázek, Y. Kobayashi, and R. MarinšekLogar. 2003. Butyrivibrio hungatei sp. nov. and Pseudobutyrivibrio xylanivorans sp. nov., butyrate-producing bacteria from the rumen. Int. J. Syst. Evol. Microbiol. 53:201-209. https://doi.org/10 .1099/ijs.0.02345-0.

Kröger, I., E. Humer, V. Neubauer, N. Kraft, P. Ertl, and Q. Zebeli. 2016. Validation of a noseband sensor system for monitoring ruminating activity in cows under different feeding regimens. Livest. Sci. 193:118-122. https://doi.org/10.1016/j.livsci.2016.10.007.

Kweon, O. K., H. Ono, K. Osasa, M. Onda, K. Oboshi, H. Uchisugi, S. Kurosawa, H. Yamashina, and H. Kanagawa. 1986. Factors affecting serum total cholesterol level of lactating Holstein cows. Nippon Juigaku Zasshi 48:481-486. https://doi.org/10.1292/jvms1939.48 .481 .

Leonardi, C., and L. E. Armentano. 2003. Effect of quantity, quality, and length of alfalfa hay on selective consumption by dairy cows. J. Dairy Sci. 86:557-564. https://doi.org/10.3168/jds.S0022 -0302(03)73634-0.

Liepa, G. U., D. C. Beitz, and J. R. Linder. 1978. Cholesterol synthesis in ruminating and nonruminating goats. J. Nutr. 108:535-543. https://doi.org/10.1093/jn/108.3.535.

Liu, L., D. Sun, S. Mao, W. Zhu, and J. Liu. 2019. Infusion of sodium butyrate promotes rumen papillae growth and enhances expression of genes related to rumen epithelial VFA uptake and metabolism in neonatal twin lambs. J. Anim. Sci. 97:909-921. https://doi.org/ $10.1093 /$ jas/sky459.

Macmillan, K., X. Gao, and M. Oba. 2017. Increased feeding frequency increased milk fat yield and may reduce the severity of subacute ruminal acidosis in higher-risk cows. J. Dairy Sci. 100:1045-1054. https://doi.org/10.3168/jds.2016-11337.

Martel, C. A., E. C. Titgemeyer, L. K. Mamedova, and B. J. Bradford. 2011. Dietary molasses increases ruminal $\mathrm{pH}$ and enhances ruminal biohydrogenation during milk fat depression. J. Dairy Sci. 94:3995-4004. https://doi.org/10.3168/jds.2011-4178.

Molento, C. F. M., E. Block, R. I. Cue, and D. Petitclerc. 2002. Effects of insulin, recombinant bovine somatotropin, and their interaction on insulin-like growth factor-1 secretion and milk protein production in dairy cows. J. Dairy Sci. 85:738-747. https://doi.org/10 .3168/jds.S0022-0302(02)74131-3.

Naumann, C., and R. Bassler. 2012. Handbuch Der Landwirtschaftlichen Versuchs-Und Untersuchungsmethodik (VDLUFA-Methodenbuch), Bd. III Die Chemische Untersuchung von Futtermitteln.

Oba, M., and M. S. Allen. 2003. Effects of corn grain conservation method on feeding behavior and productivity of lactating dairy cows at two dietary starch concentrations. J. Dairy Sci. 86:174183. https://doi.org/10.3168/jds.S0022-0302(03)73598-X.

Oba, M., J. L. Mewis, and Z. Zhining. 2015. Effects of ruminal doses of sucrose, lactose, and corn starch on ruminal fermentation and expression of genes in ruminal epithelial cells. J. Dairy Sci. 98:586594. https://doi.org/10.3168/jds.2014-8697.

Offner, A., A. Bach, and D. Sauvant. 2003. Quantitative review of in situ starch degradation in the rumen. Anim. Feed Sci. Technol. 106:81-93. https://doi.org/10.1016/S0377-8401(03)00038-5.
Penner, G. B., J. R. Aschenbach, G. Gäbel, R. Rackwitz, and M. Oba. 2009. Epithelial capacity for apical uptake of short chain fatty acids is a key determinant for intraruminal $\mathrm{pH}$ and the susceptibility to subacute ruminal acidosis in sheep. J. Nutr. 139:1714-1720. https://doi.org/10.3945/jn.109.108506.

Plaizier, J. C., D. O. Krause, G. N. Gozho, and B. W. McBride. 2008 Subacute ruminal acidosis in dairy cows: The physiological causes, incidence and consequences. Vet. J. 176:21-31. https://doi.org/10 .1016 /j.tvjl.2007.12.016.

Razzaghi, A., R. Valizadeh, A. A. Naserian, M. D. Mesgaran, A. J. Carpenter, and M. H. Ghaffari. 2016. Effect of dietary sugar concentration and sunflower seed supplementation on lactation performance, ruminal fermentation, milk fatty acid profile, and blood metabolites of dairy cows. J. Dairy Sci. 99:3539-3548. https://doi .org/10.3168/jds.2015-10565.

Rigout, S., C. Hurtaud, S. Lemosquet, A. Bach, and H. Rulquin. 2003. Lactational effect of propionic acid and duodenal glucose in cows. J. Dairy Sci. 86:243-253. https://doi.org/10.3168/jds.S0022 $-0302(03) 73603-0$

Rius, A. G., J. A. D. R. N. Appuhamy, J. Cyriac, D. Kirovski, O. Becvar, J. Escobar, M. L. McGilliard, B. J. Bequette, R. M. Akers, and M. D. Hanigan. 2010. Regulation of protein synthesis in mammary glands of lactating dairy cows by starch and amino acids. J. Dairy Sci. 93:3114-3127. https://doi.org/10.3168/jds.2009-2743.

van Knegsel, A. T. M., H. Van den Brand, J. Dijkstra, and B. Kemp. 2007. Effects of dietary energy source on energy balance, metabolites and reproduction variables in dairy cows in early lactation. Theriogenology 68:S274-S280. https://doi.org/10.1016/j .theriogenology.2007.04.043.

van Knegsel, A. T. M., H. Van Den Brand, J. Dijkstra, S. Tamminga, and B. Kemp. 2005. Effect of dietary energy source on energy balance, production, metabolic disorders and reproduction in lactating dairy cattle. Reprod. Nutr. Dev. 45:665-688. https://doi.org/ 10.1051/rnd:2005059.

Van Soest, P. J. 1994. Nutritional Ecology of the Ruminant. 2nd ed. Cornell University Press, Ithaca, NY.

Weiss, W. P., and J. M. Pinos-Rodríguez. 2009. Production responses of dairy cows when fed supplemental fat in low- and high-forage diets. J. Dairy Sci. 92:6144-6155. https://doi.org/10.3168/jds.2009 -2558 .

Westwood, C. T., I. J. Lean, and J. K. Garvin. 2002. Factors influencing fertility of Holstein dairy cows: A multivariate description. J. Dairy Sci. 85:3225-3237. https://doi.org/10.3168/jds.S0022 $-0302(02) 74411-1$

Winkelman, L. A., and T. R. Overton. 2013. Long-acting insulins alter milk composition and metabolism of lactating dairy cows. J. Dairy Sci. 96:7565-7577. https://doi.org/10.3168/jds.2012-6498.

Zebeli, Q., J. R. Aschenbach, M. Tafaj, J. Boguhn, B. N. Ametaj, and W. Drochner. 2012. Invited review: Role of physically effective fiber and estimation of dietary fiber adequacy in high-producing dairy cattle. J. Dairy Sci. 95:1041-1056. https://doi.org/10.3168/ jds.2011-4421.

Zebeli, Q., M. Tafaj, H. Steingass, B. Metzler, and W. Drochner. 2006. Effects of physically effective fiber on digestive processes and milk fat content in early lactating dairy cows fed total mixed rations. J. Dairy Sci. 89:651-668. https://doi.org/10.3168/jds.S0022 $-0302(06) 72129-4$

\section{ORCIDS}

A. Kaltenegger $\odot$ https://orcid.org/0000-0002-5782-7178

E. Humer @ https://orcid.org/0000-0001-9776-0353

A. Stauder (1) https://orcid.org/0000-0002-7948-1753

Q. Zebeli ๑ https://orcid.org/0000-0001-5188-9004 